\title{
TRANSVERSAL ANALYSIS OF SCOLIOTIC DISORDERS AT YOUNG ADOLESCENTS FROM URBAN AND RURAL AREAS
}

\author{
Radomir Čanjak ${ }^{1}$, Veselin Jovović ${ }^{2}$, Milovan Stamatović ${ }^{3}$ \\ ${ }^{1}$ Center for Preventive Corrective Gymnastics "Turn" - Nikšić, Montenegro \\ ${ }^{2}$ Faculty of Sports and Physical Education of the University of Montenegro, Montenegro, \\ ${ }^{3}$ The Faculty of Pedagogy, Užice, Serbia
}

Summary.

\begin{abstract}
The main aim of the research is to determine the frequency, severity, structure, and possible differences of spinal disorders among the girls from urban and rural areas in Montenegro. Research of transversal character included 155 female respondents, 77 of whom were from urban and 78 from rural areas, the average age 13.7 years. The analysis of scoliotic disorders was performed by using several combined techniques and methods of measurement: somatoscopy method, method by using plumb line and ruler, test of raising hand on the concave side of the body, Adams test, test of "voluntary" muscle contraction and higher position test (Koturović \& Jeričević, 1998; Živković, 1998; Radisavljević, 2001; Jovović, 2008). Frequency distribution of interrupted statistical series has been calculated for all postural variables and their variations. The differences between the subsamples of respondents were tested using the chi-square test. The results of the research indicate that the frequency of scoliotic disorders is present in great number of younger respondents in Montenegro. Statistically significant differences have not been confirmed between the respondents from urban and rural areas. The research showed that the largest percentage of deviations from the functional disorders, in both subsamples, which can be successfully corrected with the adequate application of physical treatments.
\end{abstract}

Key words: spine, scoliosis, girls, environment, differences.

\section{Introduction}

Scoliosis (Greek: scolios - oblique, slanted) represents a sideway curvature of the spine in the frontal plane, with or without the rotation or torsion of vertebrae. A great number of research indicates that scoliosis is one of the most frequent deviations in young people (Jovović, 1999; Radisavljević, 2001; Đonovic et al.; 2008 Jovović \& Čanjak 2011). It can be located in the neck, chest or groin, and along the entire spine. Based on the degree of damage of the parts of locomotor apparatus there is functional and structural scoliosis. The etiology of idiopathic scoliosis, in other words definite deformity, still remains unclear, despite the medical experience of 4000 years (Jandric, 2012). It has been established that the prevalence of scoliosis and scoliotic body posture is great in school children and young people and varies from 40 to 70\%, depending on the sex, age, environment, etc. (Jovović, 1999; Karaleić, 2006; Kovač, 2000, according to Đonović et al., 2008; Krsmanović et al., 2010). According to the specially designed measuring instrument Paušić et al. (2009) have found scoliotic body posture in $80,6 \%$ of examinees, 10 to 13 years of age. Great sensitivity of the organism to adverse environmental effects contribute to this during puberty thus increasing the possibility of postural disorders. (Radisavljević, 2001; Jovović \& Čanjak, 2011). 
A main problem lies in the fact that the number of children with bad body posture is increasing every year. (Lafond et al., 2007), as well as the number of children who complain of back pain (Watson et al. 2002). The situation is aggravated if the children are physically inactive during adolescence, thus the negative influence of hypocinesia is reflected in health and basic function of osteomuscular system and body posture.

\section{Materials and methods}

A transversal research included 23 primary schools in Montenegro, 23 from rural areas (R) and 3 from urban areas (U). The sample comprised 155 seventh-grade female students (G), average age 13,7 years, 77 from urban and 78 from rural areas. We have established severity and structure of scoliotic deviation by applying the following variables:

1. Scoliosis (skoliosis) - (SKL - suma)

- Complete scoliosis (TOT)

- Compensatory scoliosis (COM)

- Partial scoliosis (PAR)

2. Evaluated location of partial scoliosis (PAR)

- Cervical scoliosis (CER)

- Thoracic scoliosis (TOR)

- Thoracolumbar scoliosis (TLB)

- Lumbar scoliosis (LUM)

The evaluation of spine deviations was conducted by a series of combined techniques and measuring methods: somatoscopic method, measuring method by a ruler and a plumb line, maximum isometric voluntary contraction test, raising hand on the concave side of the body, Adam's test, and vertical jump test (Koturović \& Jeričević, 1988; Živković, 1998; Radisavljević, 2001; Jovović, 2008). The location, severity and structure of the deviation were established by the inspection, measurement methods, and testing. Numerical marking method was applied for the evaluation of analyzed variables: 1 - functional, 2 - insufficiently fixed deformity and 3 - fixed, or structural deformity (Jovović, 1999).

According to the program of this research, frequency distribution of practical statistical series were evaluated for all variables. The differences between subsamples were tested by means of chi-square test $\left(\chi^{2}\right)$. Mathematical and statistical analysis of the given data was conducted using statistical package „SPSS 17“and Microsoft Office Excel.

\section{Results}

The research has shown that the frontal deviations of the spine are present in young female adolescents to a large extent in Montenegro (Table 1 and Graph 1).

According to the obtained results scoliosis is almost equally present in young girls from urban and rural areas. Its prevalence is evident in more than half of the examined girls in both urban and rural areas. The results of the research have shown that the functional deviations are far more present in both subsamples. ( $\mathrm{Rf}=80.8 \%$ in urban and $38.8 \%$ in rural areas). Unlike functional deviations, more severe types of scoliosis are more common in girls from rural areas. Incompletely fixed deformities, or better say those that could not be corrected by a "voluntary" contraction, were registered in $12.8 \%$ of girls from urban, and $43.1 \%$ from rural areas. Fixed or structural scoliosis is present in $6.4 \%$ of the girls from urban and, $18.1 \%$ from rural areas, which is very disturbing. 
Table 1. Frequency of scoliosis in girls of different socio-economic background and their distribution according to the shape and location of deviations.

\begin{tabular}{|c|c|c|c|c|c|c|c|c|c|c|c|c|c|}
\hline \multirow[b]{3}{*}{ Varia. } & \multirow[b]{3}{*}{ I } & \multicolumn{9}{|c|}{ 1. Scoliosis evaluation } & \multirow{2}{*}{\multicolumn{3}{|c|}{ Sum }} \\
\hline & & \multicolumn{3}{|c|}{1} & \multicolumn{3}{|c|}{2} & \multicolumn{3}{|c|}{3} & & & \\
\hline & & $\mathrm{N}$ & $\%$ & $\mathrm{Rf} \%$ & $\mathrm{~N}$ & $\%$ & $\mathrm{Rf} \%$ & $\mathrm{~N}$ & $\%$ & $\mathrm{Rf} \%$ & $\mathrm{~N}$ & $\%$ & $\mathrm{Rf} \%$ \\
\hline SKL & $\mathrm{U}$ & 38 & 49.4 & 80.8 & 6 & 7.8 & 12.8 & 3 & 3.9 & 6.4 & 47 & 61.1 & - \\
\hline Suma & $\mathrm{R}$ & 17 & 21.8 & 38.8 & 19 & 24.4 & 43.1 & 8 & 10.3 & 18.1 & 44 & 56.5 & - \\
\hline \multirow[t]{2}{*}{$\mathrm{COM}$} & U & 17 & 22.0 & 77.3 & 2 & 2.5 & 9.0 & 3 & 3.9 & 13.7 & 22 & 28.4 & 46.8 \\
\hline & $\mathrm{R}$ & 5 & 6.4 & 29.6 & 11 & 14.2 & 64.8 & 5 & 6.4 & 29.6 & 21 & 26.9 & 47.7 \\
\hline \multirow[t]{2}{*}{ TOT } & $\mathrm{U}$ & 2 & 2.6 & 100.0 & - & - & - & - & - & - & 2 & 2.6 & 4.3 \\
\hline & $\mathrm{R}$ & 1 & 1.3 & 25.0 & 3 & 3.8 & 75.0 & - & - & - & 4 & 5.1 & 9.1 \\
\hline \multirow[t]{2}{*}{ PAR } & $\mathrm{U}$ & 19 & 24.7 & 82.6 & 4 & 5.2 & 17.4 & - & - & - & 23 & 29.8 & 48.9 \\
\hline & $\mathrm{R}$ & 11 & 14.1 & 57.8 & 5 & 6.4 & 26.3 & 3 & 3.8 & 15.9 & 19 & 24.3 & 43.2 \\
\hline
\end{tabular}

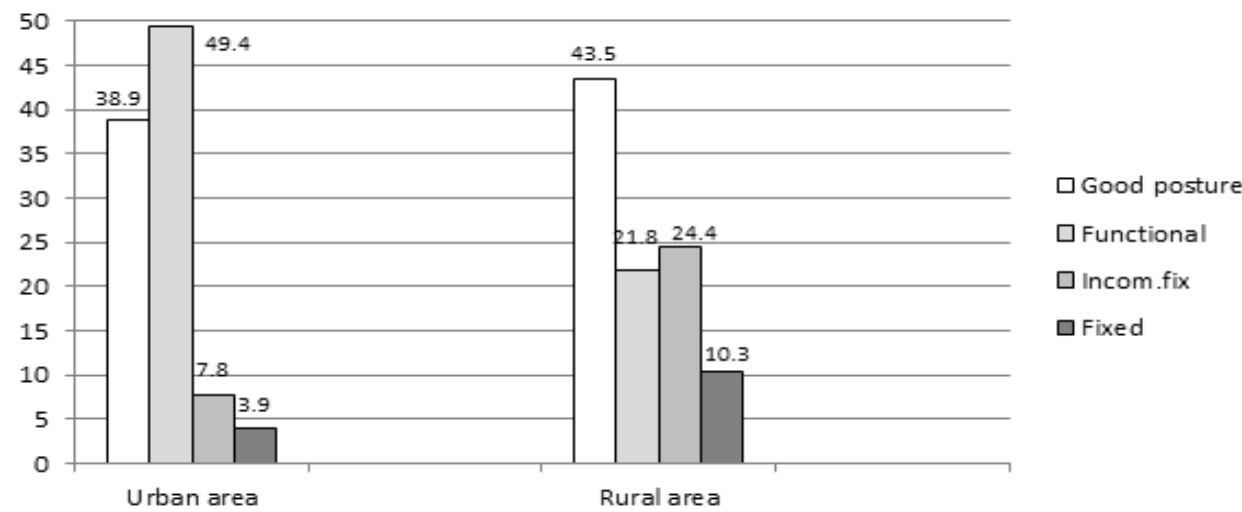

Graph 1. Frequency results of scoliosis of female pupils of different socio-economic background

According to the structure of scoliosis, or the location and the type of deformity in the frontal plane it has been observed that the partial (PAR) and compensatory (COM) types of scoliosis are most common, with approximately similar results in both examined groups (Table 1). Total scoliosis (TOT) is the least common of them all, especially in the group of girls from urban areas.

Table 2. Frequency of partial scoliosis in girls depending on the location of deviation

\begin{tabular}{|c|c|c|c|c|c|c|c|c|c|c|c|c|c|}
\hline \multirow[b]{3}{*}{ Varia. } & \multirow[b]{3}{*}{ I } & \multicolumn{9}{|c|}{ 2. The evaluation of partial scoliosis location } & \multirow{2}{*}{\multicolumn{3}{|c|}{ Sum }} \\
\hline & & \multicolumn{3}{|c|}{1} & \multicolumn{3}{|c|}{2} & \multicolumn{3}{|c|}{3} & & & \\
\hline & & $\mathrm{N}$ & $\%$ & $\mathrm{Rf} \%$ & $\mathrm{~N}$ & $\%$ & Rf\% & $\mathrm{N}$ & $\%$ & Rf\% N & $\%$ & Rf\% & \\
\hline \multirow[t]{2}{*}{$\overline{\text { CER }}$} & $\mathrm{U}$ & 6 & 7.8 & 85.7 & 1 & 1.3 & 14.3 & - & - & - & 7 & 9.1 & 30.4 \\
\hline & $\mathrm{R}$ & 1 & 1.3 & 16.7 & 3 & 3.8 & 50.0 & 2 & 2.6 & 33.3 & 6 & 7.1 & 31.6 \\
\hline \multirow[t]{2}{*}{ TOR } & $\mathrm{U}$ & 11 & 14.3 & 100.0 & - & - & - & - & - & - & 11 & 14.3 & 52.3 \\
\hline & $\mathrm{R}$ & 8 & 10.2 & 80.0 & 1 & 1.3 & 10.0 & 1 & 1.3 & 10.0 & 10 & 12.8 & 52.7 \\
\hline \multirow[t]{2}{*}{ TLB } & $\mathrm{U}$ & 2 & 2.6 & 50.0 & 2 & 2.6 & 50.0 & - & - & - & 4 & 5.2 & 17.3 \\
\hline & $\mathrm{R}$ & 2 & 2.6 & 66.6 & 1 & 1.3 & 33.4 & - & - & - & 3 & 3.9 & 15.7 \\
\hline \multirow[t]{2}{*}{ LUM } & $\mathrm{U}$ & - & - & - & - & - & - & - & - & - & - & - & - \\
\hline & $\mathrm{R}$ & - & - & - & - & - & - & - & - & - & - & - & - \\
\hline
\end{tabular}


The results of this research have shown that partial scoliosis (PAR) is differently distributed in girls from urban and rural areas (Table 2 and Graph 2). Thoracic scoliosis is most present (TOR), often with the top of the curve at the height of V and VII thoracic vertebrae, and often with left convexity. One school girl had the most severe form of this deformity. Somewhat lower percent refers to cervical scoliosis (CER), structural form of this deformity has been detected in two girls from rural areas (CER). A detailed investigation of the girls indicated that it was the case of a curve in the neck. There was a significantly lower number of cases of thoracolumbar scoliosis (TLB). All three types of scoliosis have proven to be similarly distributed in girls from different socio economic background. It is interesting to note that lumbar (LUM) has not been registered in girls who participated in this research.

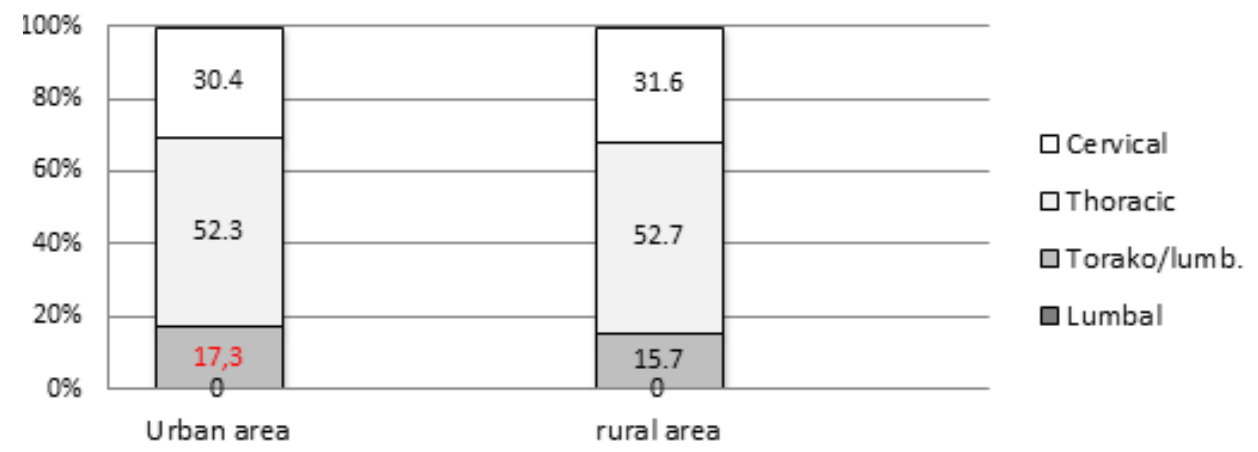

Graph 2. Relative frequency of partial scoliosis in girls depending on the location of deviation

Based on the analysis of Table 3 it has been shown that there is no significant difference in the frequency of scoliosis between the girls of urban and rural areas, because the level of statistical significance of the chi-square test (Jates correlation) is far greater than it is allowed $\mathrm{p} \leq 0.05$.

Table 3. The significance of frequency differences of scoliosis between girls from rural and urban environments

\begin{tabular}{lcc}
\hline Variable & $\mathrm{C}^{2}$ & $\mathrm{p}$ \\
\hline Scoliosis & 0,17 & 0,67 \\
\hline
\end{tabular}

\section{Discussion}

The results of this research have confirmed that there is a great frequency of scoliotic deviations in girls and that it is fairly equally present in girls of different socio-economic background in Montenegro. Their frequency, scope and structure is almost identical with boys of the same age from Montenegro. (Jovović \& Čanjak, 2014). Such a high percentage of scoliosis prevalence in young adolescents is usually the consequence of a bad body posture which additionally burdens the locomotor apparatus. Besides bad body posture, carrying heavy school bags has a negative effect on stato-dynamic relations on the locomotor apparatus. It is well known that in some European countries there is a law which requires that school bags should not weigh more than $10 \%$ of child's body weight. The research conducted in our country and worldwide has shown that the weight of a schoolbag 
exceeds the allowed values and varies from 10 to $14 \%$ of the total body weight (Fošnarič \& Smrečnik, 2007), or 15,3\% (Jovović \& Čanjak, 2016), and even up to $20 \%$ of the total body weight (Watson et al. 2002). Therefore, special attention should be paid to negative influences at this age because the body sensitivity to the adverse environmental effects is increased in puberty (Živković, 1998; Radisavljević, 2001; Jovović, 2008).

This research has shown that functional scoliosis is more present in girls from urban areas. The reason for this often lies in the fact that the locomotor apparatus of city children is pretty sensitive. Its sensitivity is increased because of the earlier entrance into puberty. However, a greater number of incompletely-fixed and structural scoliosis is more present in girls from rural areas. This leads us to the conclusion that life in the country does not necessarily mean "a healthy life" in all aspects, but that it has some flaws as well. This indicates that the number of causes which lead to spinal deformities is much greater. Therefore James (1967; according to: Jovović, 2008) says that there are more than 50 etiological causes of spinal deformities, the most common being the following: hereditary factors, various diseases, adolescence, uncomfortable beds, etc.

A great frequency of so called compensatory scoliosis (COM) characterized by the " $\mathrm{S}$ " shape of the spine has been established. There were two curvature of the spine, primary and secondary. Namely, the appearance of one disorder leads to the other on the opposite side of the spine, which is the result of compensatory movements of certain spinal segments in order to achieve balance. (Živković, 1998; Radisavljević, 2001; Jovović, 2008).

Partial scoliosis (PAR) is also common in girls from urban and rural areas. They are characterized by the fact that they affect only some spinal segments and they often have the shape of the letter "C". Thoracic scoliosis (TOR) was mostly of functional type, thus it could be treated with an adequate treatment. This type of scoliosis is often found in young children (4-6 years of age) and adolescents. The most progressive type is the one which occur after the age of 10, or the beginning of puberty (Radisavljević, 2001; Jovović, 2008).

Such a great number of posture disorders indicate that preschool and school children should do exercises every day in order to strengthen their body, and improve general physical status. When the body is strengthen in childhood and with the appropriate physical activities it is certain that the negative consequences of modern lifestyle would be easier to overcome. It is very important to teach young people to keep good body posture in everyday situations where certain body positions are maintained for a longer period of time. Furthermore, it is important to provide furniture which is adapted to the age of a child and teach children to properly carry their school bags, as well as to acquire good habits such as, regular moderate physical activity and a healthy diet. Special attention should be dedicated to regular health check-ups in kindergartens and schools which would provide an insight into postural status of young people. This would ensure timely and preventive actions in the period of life when body is susceptible to numerous negative causes.

\section{References}

Đonović N. Ilić M. Damjanov V. Jovanović B. Skolioza kod školske djece na teritoriji grada Kragujevca. Medicinski časopis, 2008; 1:34-38.

Fošnarič S. \& Smrečnik I. D. Physical overburderening of pupils with the weigh of school bags during the period of passing from eight year primary school to nine year primary school. Informatologia. 2007;40: 207-210.

Jandrić S. Idiopatske skolioze. Medicinski časopis. 2012; 1-2: 35-40.

Jovović V. Tjelesni deformiteti adolescenata. Filozofski fakultet, Nikšić, 1999. 
Jovović V. Čanjak R. Analiza statusa kičmenog stuba u frontalnoj ravni kod adolescenata rurarne i urbane životne sredine. Glasnik ADS. 2014; 49: 11-17.

Jovović V. Korektivna gimnastika sa kineziterapijom. Filozofski fakultet, Nikšić, 2008.

Jovović V. Čanjak R. Oscilacije devijacija kičmenog stuba kod školske djece zavisno od uzrasnog doba. Glasnik ADS. 2011; 46:369-376.

Jovović V. Čanjak R. Učestalost i struktura posturalnih poremećaja kod učenika mlađeg adolescentnog doba u Crnoj Gori. Zbornik radova „Antropološki aspekti sporta, fizičkog vaspitanja i rekreacije“, str. 113-119. Banja Luka, 2012.

Jovović V. Čanjak R. Opterećenost učenika prvog i drugog razreda osnovne škole sa školskom torbom. LIV Kongres Antropološkog društva Srbije, sa međunarodnim učešćem. Program i izvodi saopštenja, str. 86., Sremski Karlovci, 1-4. jun 2016.

Karaleić S. Posturalni status učenika višeg osnovno-školskog uzrasta.Glasnik ADS 2006; 41: 257-260.

Koturović Lj. Jeričević D. Korektivna gimnastika. IGRO “Sportska knjiga”, Beograd 1988.

Krsmanović C. Krsmanović R, Mijanović M, Jakonić D. Ocjenjivanje pravilnog držanja tijela studentkinja Novosadskog Univerziteta. Podgorica, Fizička kultura, 1995;1-2:73-76.

Krsmanović T. Krulanović R. Andrašić S. Posturalni status i antropometrijske karakteristike 20godišnjih studentkinja. Glasnik ADS. 2010; 45:391-395.

Lafond D. Descarreaux M. Normand M. C. \& Harison, D. E. Postural development in school children: a cross-sectional study. Chiropractic \& Osteopathy, 2007; 15:1746-1340.

Paušić J. Kujundžić H. i Mihalj N. Povezanost bolnog sindroma kralježnice i težine školske torbe u djece razredne nastave. Zbornik radova 18. Ljetnje škole kineziologa Republike Hrvatske 2009; 207-213.

Radisavljević M. Korektivna gimnastika sa osnovama kineziterapije. Univerzitet u Beogradu Fakultet za sport i fizičko vaspitanje, Beograd, 2001.

Živković D. Teorija i metodika korektivne gimnastike. SIA. Niš, 1998.

Velitčenko K. V. Fizkultura bez tramv. Biblioteka učitelja fizočeskoj kuljturi, Moskva, 1993.

Watson K. D. Papageorgiu A. C. Jones G. T. Symmons D. P. Silman A. J. \& Macfarlane G. J. Low back pain in schoolchildren: occurrence and characteristics. Pain, 2002;97:87-92.

\title{
TRANSVERZALNA ANALIZA SKOLIOTIČNIH POREMEĆAJA KOD MLAĐIH ADOLESCENTKINJA URBANE I RURALNE ŽIVOTNE SREDINE
}

\author{
Radomir Čanjak, Veselin Jovović, Milovan Stamatović
}

Sažetak.

\begin{abstract}
Osnovni cilj ovog istraživanja je utvrđivanje frekvencije, težine, strukture i eventualnih razlika u prisutnosti skoliotičnih poremećaja na kičmenom stubu, kod djevojčica urbane i ruralne životne sredine u Crnoj Gori. Istraživanjem transverzalnog tipa obuhvaćeno je 155 ispitanica, i to 77 iz urbane i 78 iz ruralne životne sredine, prosječne starosti 13,7 godina. Analiza skoliotičnih poremećaja izvršena je primjenom više kombinovanih tehnika i metoda mjerenja: metode somatoskopije, metode mjerenja pomoću viska i lenjira, testa „voljne“ kontrakcije mišića, testa podizanja ruke na konkavnoj strani tijela, Adamsovog testa i testa položaja u visu (Koturović i Jeričević, 1998; Živković, 1988; Radisavljević, 2001; Jovović, 2008). Za sve primijenjene posturalne varijable i njihove varijacije izračunate su distribucije frekvencija prekidnih statističkih serija. Razlike između subuzoraka ispitanica su testirane pomoću hikvadrat $\left(\chi^{2}\right)$ testa. Rezultati istraživanja su pokazali da je frekvencija skoliotičnih poremećaja u značajnoj mjeri zastupljena kod mlađih adolescentkinja u Crnoj Gori. Između ispitanica urbane i rurarlne životne sredine nijesu utvrđene razlike na statistički značajnom nivou. Istraživanje je pokazalo da kod oba subuzorka daleko najveći procenat devijacija čine funkcionalni poremećaji koji se adekvatnim tjelesnim tretmanom mogu vrlo uspješno otkloniti.
\end{abstract}

Ključne reči: kičmeni stub, skolioza, djevojčice, životna sredina, razlike. 